\title{
A identidade construída pela aparência: a moda negra no contexto norte-americano
}

The identity built by appearance: black fashion in the North American context

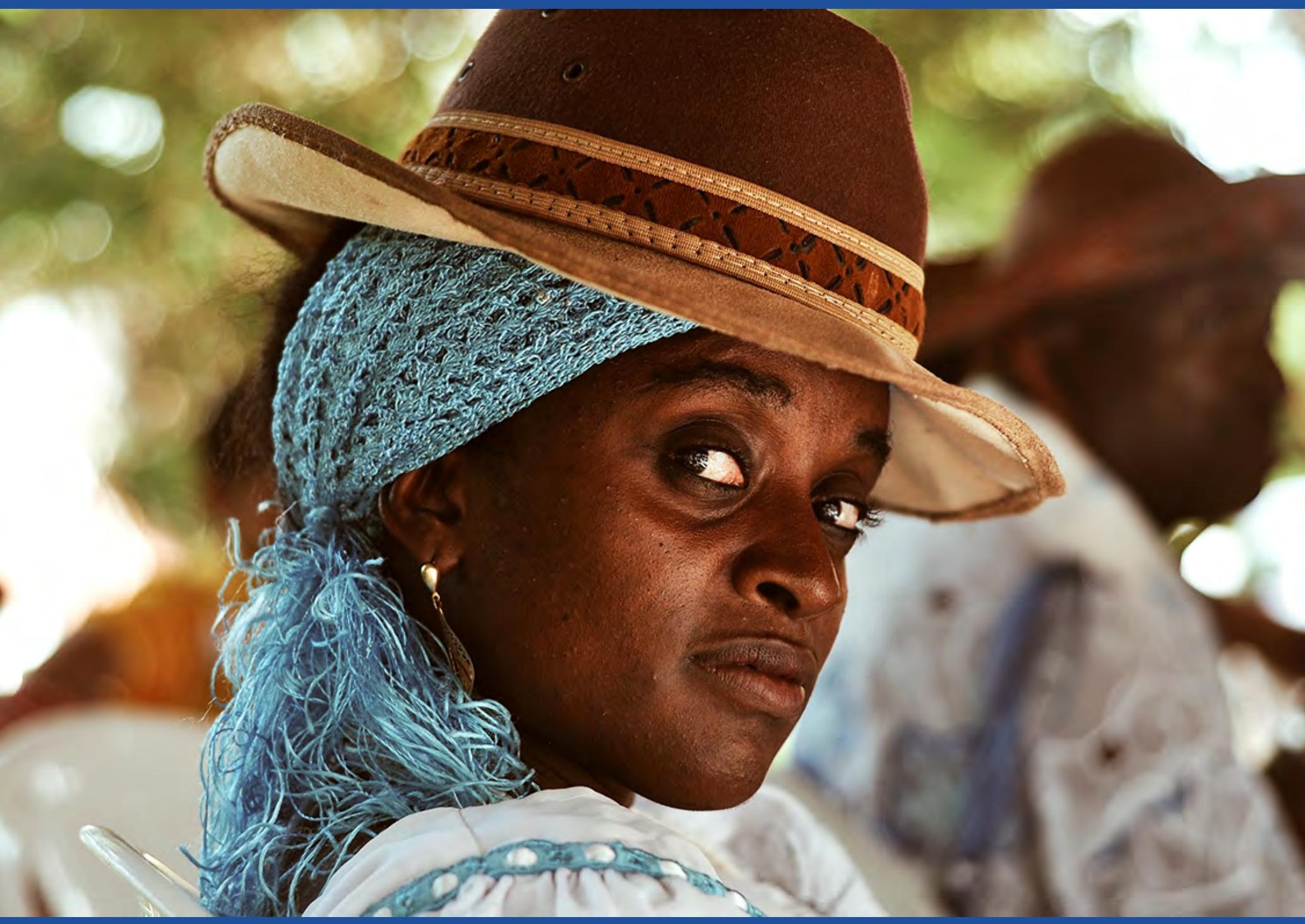




\section{Deyse Pinto de Almeida ${ }^{1}$}

ORCID: https://orcid.org/0000-0001-7048-3763

[resumo] 0 estudo das identidades surgidas ao longo do desenvolvimento das sociedades capitalistas é um processo muito rico em significados. As roupas funcionam como um meio de comunicação eficiente e fundamental no ambiente urbano, transmitindo informações de forma não verbal, mas que podem ser compreendidas por todos. Compartilhando uma experiência de sofrimento em comum, os afro-americanos construíram um repertório próprio de moda ao longo do século XX que foi importante para o reconhecimento e a identificação desse grupo frente à sociedade norte-americana. 0 objetivo deste trabalho é demonstrar a relevância das roupas para a juventude negra se reconhecer, recuperar suas origens e se orgulhar de sua imagem.

\section{[palavras-chave] Moda. Identidade. Afro-americano.}

[abstract] The study of identities that emerged during the development of capitalist societies is a process that is very rich in meaning. Clothes work as an efficient and fundamental means of communication in the urban environment, transmitting information in a non-verbal way, but that can be understood by everyone. Sharing an experience of common suffering, African Americans built their own fashion repertoire throughout the 20th century that was important for the recognition and identification of this group in the face of American society. The objective of this work is to demonstrate the relevance of clothes for black youth to recognize themselves, recover their origins and be proud of their image.

[keywords] Fashion. Identity. African-American.

Recebido em: 30-03-2020

Aprovado em: 18-06-2020

\footnotetext{
1 Doutoranda em Artes, Cultura e Linguagens pela Universidade Federal de Juiz de Fora. Mestre em Artes, Cultura e Linguagens pela Universidade Federal de Juiz de Fora. E-mail: deysepinto@hotmail. com. Lattes: http://lattes.cnpq.br/6521258393571120.
} 


\section{Introdução}

O presente trabalho tem como objetivo apresentar as articulações existentes entre a moda e o processo de formação da identidade do negro nos Estados Unidos. A identidade pode ser compreendida como um conjunto de valores e crenças compartilhado por um grupo de indivíduos. Peculiaridades que aproximam certas pessoas e também as distinguem de outras. Para Stuart Hall (2006) a identidade é construída a partir da interação do sujeito com a sociedade, em um diálogo contínuo com o mundo. Essa relação leva esse sujeito a projetar e a internalizar imagens e símbolos que irão constituir sua identidade em uma troca dinâmica e constante. Assim, a elaboração da identidade acontece na relação com as pessoas que mediam os valores, os sentidos e os símbolos, ou seja, a cultura, para o indivíduo.

As vestimentas não são apenas construções que imitam, são feições que marcam determinados desejos e valores. Existe um paradoxo que permeia esse campo, que mistura valores e mantém a indumentária em constante mutação. A moda é uma expressão da individualidade mas também é um fenômeno coletivo, a partir do momento em que determinado grupo se une e percebe semelhanças em seus interesses e aspirações, transmitindo a mesma mensagem por meio de um estilo. Essa contradição é a principal norteadora das sociedades contemporâneas, uma busca incansável pela liberdade de pensar e agir, valendo-se da diferença para obter destaque e afirmação no plano pessoal.

A representação da identidade pode ser utilizada como instrumento para a disputa de poder nas sociedades. Por se ligarem intimamente aos desejos e às vontades individuais, identidade e diferença podem ser manipuladas para manter determinado sistema de dominância ao mesmo tempo que abrem espaço para se construir um discurso de resistência. Nesse sentido, a moda contribui como um espaço rico para a observação das relações humanas em comunidade. Símbolo de status e colocação social, as roupas assumiram, ao longo do desenvolvimento da sociedade ocidental, um papel central nas formas de representação e comunicação. Gilles Lipovetsky (1989) destaca que a moda é um dos espaços sociais em que os indivíduos conseguem exercer sua liberdade e sua maneira crítica de enxergar o mundo, resultado do desejo de afirmação de uma personalidade que cada ser possui. Dessa maneira, ela pode ser compreendida como um suporte para a criação da identidade social do indivíduo.

As práticas culturais ocorridas durante a diáspora africana configuram um material rico de estudo e compreensão da adaptação e da resistência negra na América. Neste trabalho, apresentaremos uma breve trajetória da afirmação racial do negro em terras estadunidenses, enfatizando a importância do vestuário, nosso principal objeto de pesquisa.

\section{Identidade e resistência}

A forma de vestir representa uma expressão, uma manifestação particular que liga uma pessoa a um grupo social. Diana Crane (2006), em sua análise sobre o papel social da moda, enxerga que as roupas possuem uma capacidade de expressar aquilo que os indivíduos desejam. Assim, a forma como diferentes sociedades se vestem indica o modo como elas vivem e a análise das suas modificações nos permite compreender as mudanças do comportamento e da maneira de pensar de acordo com contextos diferentes. Ideias e sentimentos 
podemtambém ser identificadas a partir do modo como as pessoas se vestem. "Pela aparência que assume, um indivíduo se situa em relação aos outros, como também em relação a si mesmo. Nessas condições, a moda é um dos meios que ele utiliza para se tornar ele mesmo" (ERNER, 2005, p. 220).

Diana Crane (2006) observa que desde o século XIX, as roupas possuem um significado diferenciado para a população negra nos Estados Unidos. A autora aponta que a apresentação pessoal dos negros nos espaços de sociabilidade era um momento muito importante, estar bem-vestido na igreja aos domingos era uma tradição e servia para construir uma imagem de homens, buscando acabar com a percepção de que eles eram apenas animais utilizáveis no mundo do trabalho e descartáveis quando fosse conveniente. Crane ainda acrescenta que para os jovens negros, vestir-se bem e andar pelas ruas do bairro, olhar e ser visto funcionava como um código de distinção importante. É preciso ponderar que, naquele momento, não existia um estilo próprio elaborado e consumido exclusivamente por negros. Em uma conjuntura em que o racismo era muito presente na sociedade norte-americana, a estratégia dos negros para alcançar a respeitabilidade almejada era imitar os signos de distinção daqueles que estavam em uma posição superior. Perceba que essa imitação não era feita com base na simples admiração ou aceitação de que a comunidade negra era inferior. Para compreendermos a moda vinculada a esse processo histórico, precisamos ter em mente a necessidade que um indivíduo possui em se representar, em se impor de maneira respeitável na sociedade em que habita.

\section{FIGURA 1 - AFRO-AMERICANO NO SÉCULO XIX}

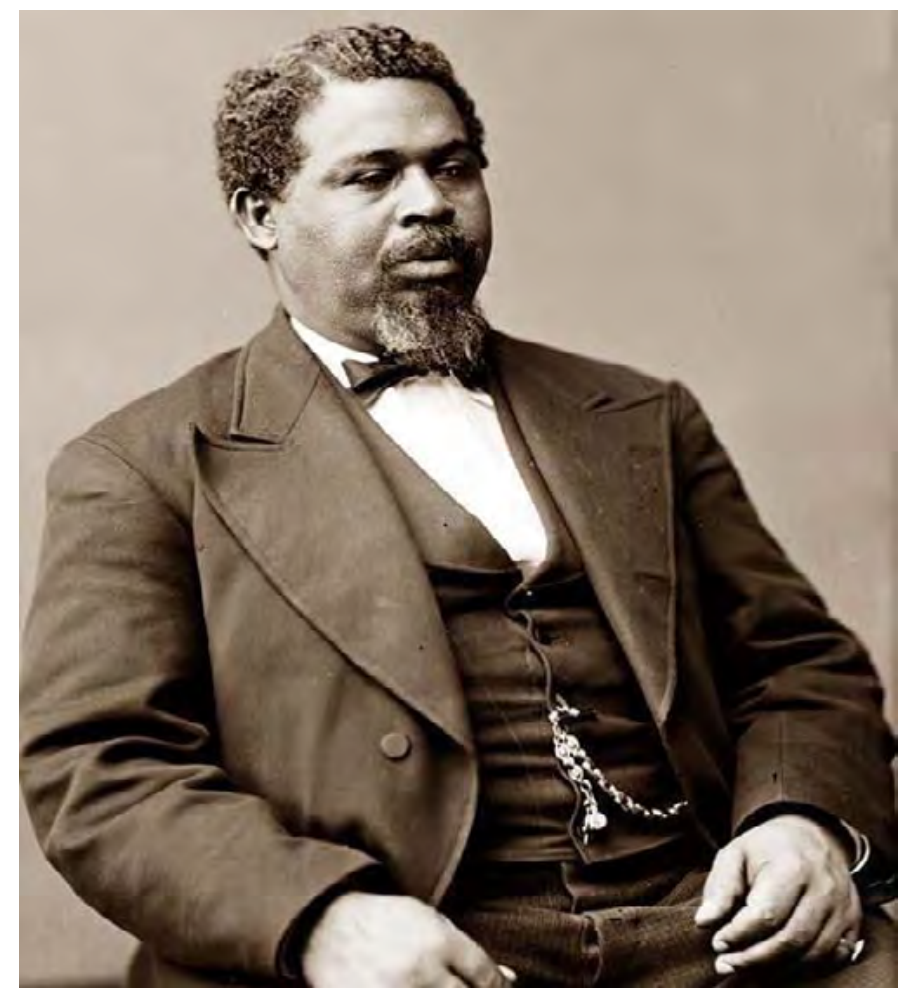

FONTE: Disponível em: http://www.old-picture.com/mathew-brady-studio/Robert-Smalls.htm. Acesso em: 1 fev. 2015. 
Stuart Hall (2003) acredita que essa apropriação de elementos da cultura dominante representava uma negociação de espaço por parte dos negros, uma forma de inserção e resistência, importante para a construção da identidade dos mesmos.

A apropriação, cooptação e rearticulação seletivas de ideologias, culturas e instituições europeias, junto a um patrimônio africano [...] conduziram a inovações linguísticas na estilização retórica do corpo, a formas de ocupar um espaço social alheio, a expressões potencializadas, a estilos de cabelo, a posturas, gingados e maneiras de falar, bem como a meios de constituir e sustentar o companheirismo e a comunidade. (HALL, 2003, p. 343).

Esse posicionamento do negro frente à cultura hegemônica inaugura a primeira experiência de inserção desse grupo em um campo simbólico que não lhe pertencia. Na figura 1, observamos Robert Smalls em fotografia feita em 1870. Escravizado que conquistou a sua liberdade durante a Guerra Civil, Smalls lutou pela igualdade entre brancos e negros no exército dos Estados Unidos, atuando como deputado na Carolina do Sul. Na imagem, vemos que Robert Smalls está vestido em conformidade com os padrões da classe média alta norte-americana e europeia do século XIX: casaco e calças, além da gravata, do colete e do relógio. Também chama atenção a presença do anel no dedo mínimo que era, frequentemente, associado à formação acadêmica. A assimilação do modo de vestir das classes dominantes era fundamental no século XIX, uma vez que as roupas transmitiam "informações tanto sobre o papel e a posição social daqueles que a vestiam quanto sobre sua natureza pessoal" (CRANE, 2006, p. 199).

Ao tratarmos da construção da identidade negra, não podemos deixar de citar a influência do fenômeno musical nesse processo. Assim como as roupas, a música atua como um veículo de comunicação, sintetizando experiências históricas e revelando uma interpretação pessoal a respeito do mundo. Nesse contexto, o surgimento do jazz na passagem do século XIX para o XX é nosso objeto de interesse, bem como a interlocução do ritmo com a moda. 0 jazz tem sua origem ligada aos subúrbios negros da cidade de Nova Orleans, no sul dos Estados Unidos. Em linhas gerais, o jazz pode ser definido como uma música de protesto. Resultado da política de segregação que separava os espaços públicos para brancos e negros que acabou levando estes a construírem estratégias que amenizassem essa condição. Em "A história social do jazz", o historiador Eric Hobsbawm (1986) destaca que a principal característica do ritmo é a improvisação e sua capacidade em misturar os instrumentos musicais considerados de elite (tal como o piano, o trompete, o saxofone) com a musicalidade de matriz africana, baseada nos spirituals ${ }^{2}$. 0 compasso acelerado do jazz combinava perfeitamente com a atmosfera vivenciada nos Estados Unidos na segunda década do século XX. A prosperidade econômica e a industrialização avançada dos chamados "Anos Loucos" fascinavam e levavam todos a crer que o desenvolvimento humano e industrial não possuía mais limites. Pela primeira vez, a cultura afro-americana atingia um patamar de destaque, sendo admirada e consumida por outros segmentos sociais.

Assim chamados os cantos entoados pelos escravos vindos da África que tinham como tema a saudade da terra natal, o sofrimento do trabalho forçado e o desejo por liberdade. 
A popularização do jazz nos anos 1920 ocorreu simultaneamente a emergência do Harlem, bairro de Nova Yorque, como capital da cultura negra. 0 fato é que no fim da Primeira Grande Guerra, os Estados Unidos firmavam-se como principal potência econômica e o estabelecimento de novas indústrias no norte do país levou a população negra a migrar para essa região em busca de empregos e de um ambiente racialmente mais tolerante. 0 Harlem recebeu trabalhadores com pouca instrução, mas também abrigou uma população afrodescendente letrada, instruída, que compartilhava suas experiências de cativeiro, luta por reconhecimento e emancipação. Assim surgia o movimento artístico-literário Harlem Renaissance, que defendia a autodeterminação dos negros e concedia, pela primeira vez na história, espaço para que as memórias, os desejos e as aspirações dessa comunidade fossem expostas no meio artístico. Nesse contexto, muitos autores reforçam a ideia de união da raça negraem defesa de uma identidade pura, que fosse completamente diferente do mundo pregado pela dominação dos homens brancos. 0 Harlem Renaissance abrangia prosa, poesia, escultura, pintura, dança e jazz, diferentes manifestações artísticas financiadas por uma elite branca que admirava a excentricidade e a diferença da cultura negra.

\section{FIGURA 2 - O VESTUÁRIO NEGRO NA ERA DO JAZZ REPRESENTADO}

PELO MÚSICO LOUIS ARMSTRONG, EM 1927

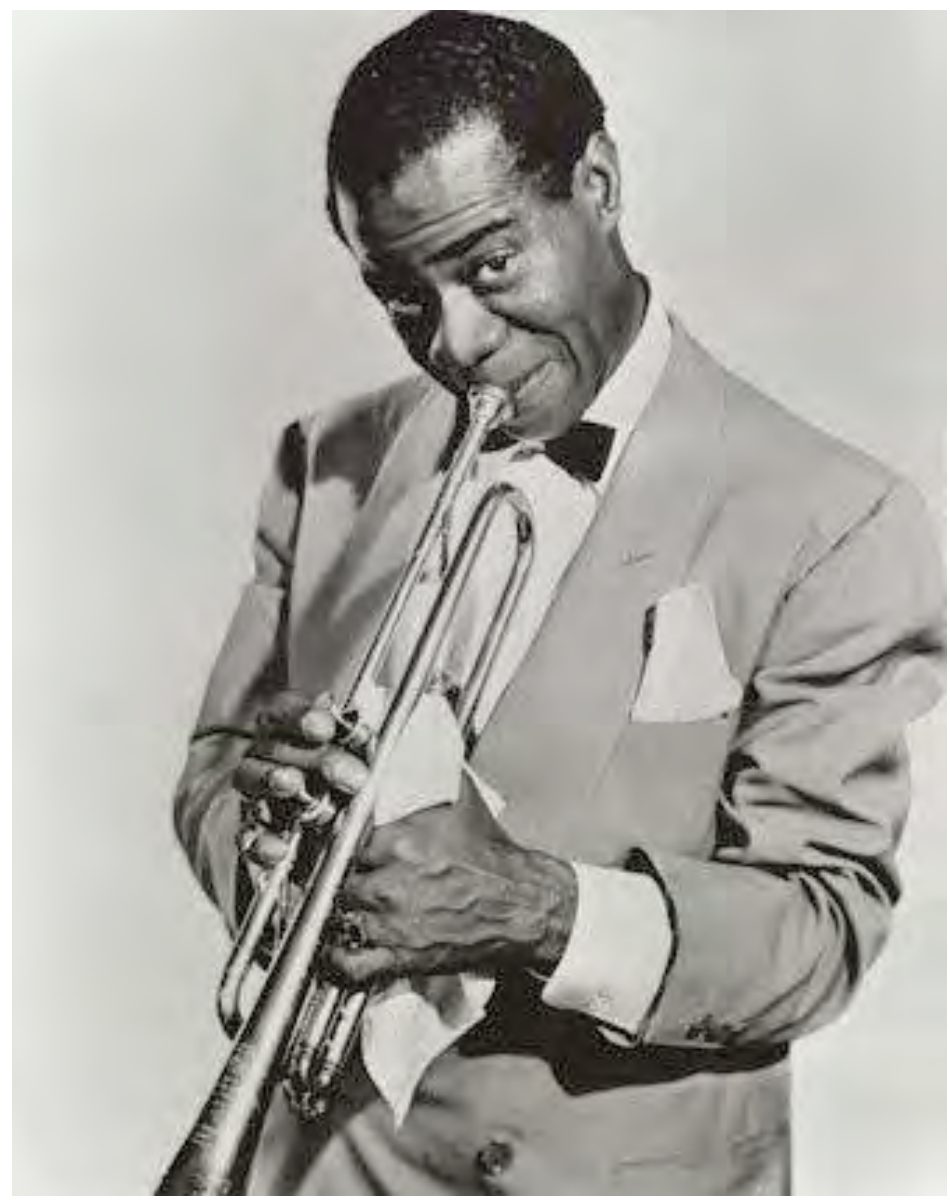

FONTE: Disponível em: http://musica.culturamix.com/estilos/jazz/louis-armstrong.

Acesso em: 2 fev. 2015. 
Na figura 2, conseguimos observar que apesar da grande visibilidade alcançada durante os anos 1920 e 1930, os músicos negros que se dedicavam ao jazz vestiam-se da mesma maneira que a elite branca do período: com uma silhueta elegante, calças mais frouxas, ausência do colete e um indispensável lenço no bolso do paletó mais amplo. Nesse momento, o comportamento social dos negros em ascensão se encontrava bem distante do estilo de vida das camadas mais populares, uma vez que eram os símbolos e os valores da elite branca almejados. É preciso esclarecer que essa conduta não significava uma negação das origens ou uma espécie de vergonha por ser negro. Conforme Silva (1990) observa em seu estudo sobre o comportamento dos afro-americanos na década de 1920,

a elite negra procurava, portanto, afirmar-se como negra, mas de forma oposta ao negro pobre dos porões. Procuravam marcar a alteridade e estabelecer suas fronteiras, a partir da afirmação contraditória da condição negra, porém sob os padrões brancos de conduta social. (SILVA, 1990, p. 112)

Ao investigarmos a evolução do vestuário na história humana é comum observarmos a existência de grupos minoritários que escolhem se encaixar nas normas e nos padrões vigentes em busca de colocação social. Kabengele Munanga (2009) pontua que se vestir como o branco era uma forma de os negros pretenderem a sua aceitação mas, na prática, não conseguiam a visibilidade almejada, tornando-se "macaquinhos de imitação", ridicularizados pelo opressor. Dessa forma, "a liberação do negro deve efetuar-se pela reconquista de si e de uma dignidade autônoma" (MUNANGA, 2009, p. 43). Pela assimilação não viria a aceitação e as tensões existentes no plano social também podem ser divulgadas a partir da formação de novos conceitos e novas direções observadas nas maneiras de vestir.

A crise econômica deflagrada em 1929 atingiu em cheio o Harlem, com a diminuição dos empregos e a redução do apoio financeiro aos movimentos artísticos. No entanto, o impacto causado na era áurea não podia ser apagado e se manifestaria nas gerações seguintes. Em meados da década de 1930, em meio à discriminação econômica e social, emergia o zoot suit, um estilo de terno mais largo, menos tradicional, marcado pelas calças engomadas na altura da cintura e pelos paletós gigantescos (às vezes, com tamanho duas ou três vezes maior que o normal) que vinham até os joelhos, com ombreiras e, comumente, coloridos. Compunham o visual, enormes correntes douradas (ou relógios que nunca eram consultados), que desciam abaixo dos casacos, sapatos bicolores e chapéus que poderiam ter abas largas ou menores, utilizados bem ao alto da cabeça. De acordo com Diana Crane (2006):

Confeccionado em cores fortes (como azul-celeste), com chapéu combinando, usado com uma longa corrente dourada e um cinto com monograma, o terno zoot imediatamente identificava quem o vestia como parte de uma cultura diversa da branca, pois era oferecido apenas em bairros negros e usado somente por negros e hispânicos. 0 traje era uma afirmação contundente da identidade negra; representava 'uma recusa subversiva a ser subserviente. (CRANE, 2006, p. 361-362)

Segundo Ted Polhemus (1994), essa releitura do terno ia de encontro a uma tendência do vestuário masculino que, desde o fim do século XVIII, apontava para uma postura 
mais discreta, menos suntuosa, livre de extravagâncias, valorizando mais a ética do trabalho e o conservadorismo. 0 fato é que o estilo zoot ${ }^{3}$ representa uma nova etapa no processo de negociação dos afro-americanos com sua aparência e identidade, representado um avanço na maneira como os negros interpretam seus gostos e utilizam os elementos de vestuário que estão à sua disposição.

\section{FIGURA 3 - CAB CALLOWAY EM PUBLICIDADE PARA O MUSICAL JAZZ STORMY WEATHER, EM 1943}

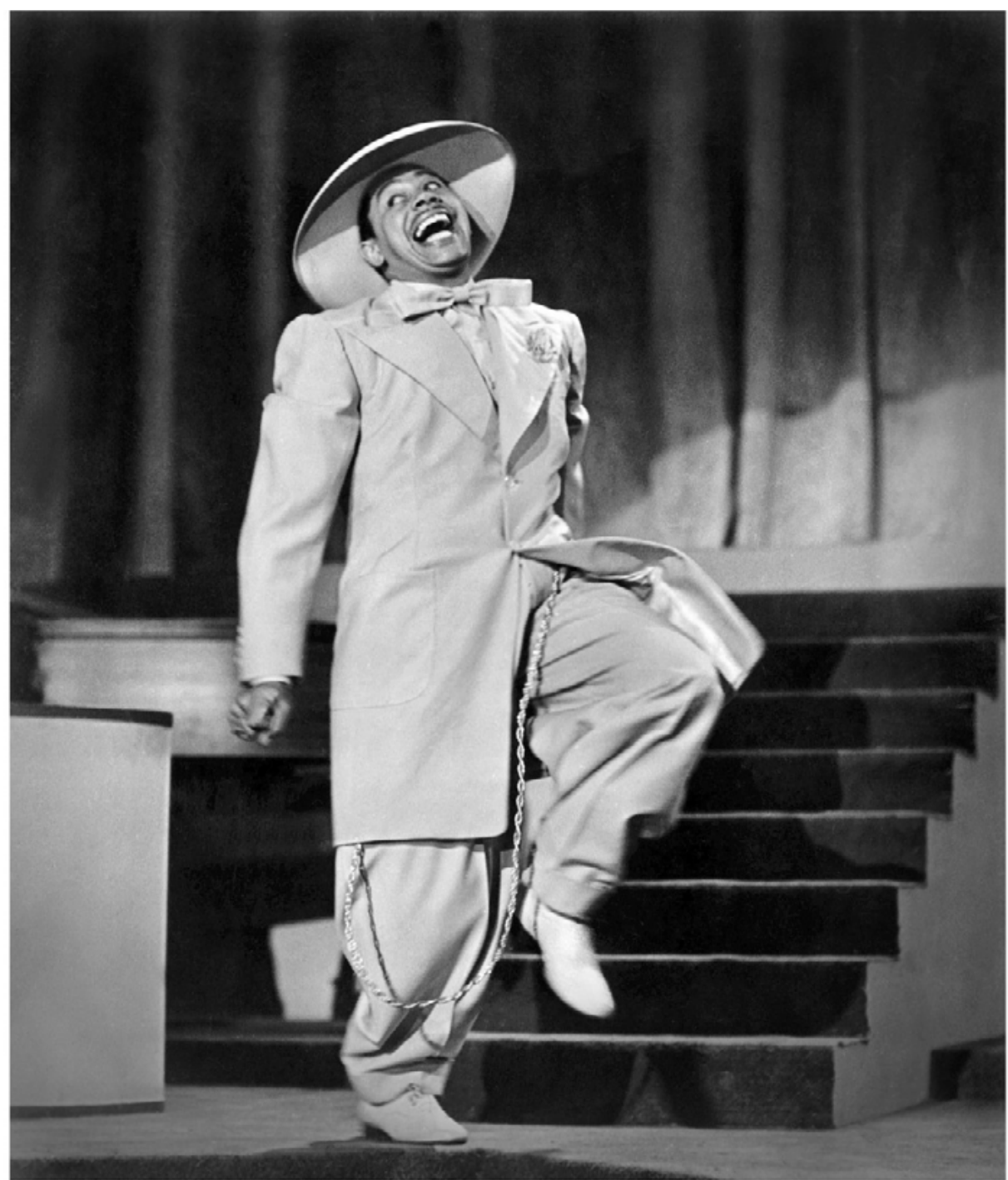

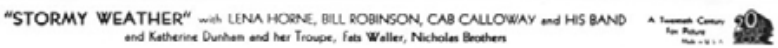

FONTE: Disponível em: https://www.insidehook.com/daily_brief/news-opinion/how-the-zoot-suitdefined-an-era-and-why-it-was-banned-by-the-government. Acesso em: 1 mar. 2020.

\footnotetext{
3 Os ternos em estilo zoot também foram muito populares entre os imigrantes de origem latina, sobretudo os mexicanos que chegaram em expressivo número aos Estados Unidos entre as décadas de 1930 e 1940.
} 
Inicialmente, essa peculiar forma de se vestir era considerada apenas um exemplo de mau gosto, símbolo de uma população degenerada por natureza. De acordo com Patrice Bollon (1993), toda essa exuberância "encontrava razão de ser na sua ausência de razão, sua finalidade se confundia com a falta de finalidade" (BOLLON, 1993, p. 81). O que transforma o terno zoot em uma roupa ligada à subversão é a mudança no cenário social norte-americano provocada pela entrada do país na guerra. A partir de 1942, itens de primeira necessidade, tecidos incluídos, precisavam ser racionados. Todo o esforço deveria ser realizado para que as tropas aliadas fossem conduzidas à vitória. Nesse sentido, o Conselho de Produção de Guerra, nos Estados Unidos, determinou que a lã utilizada em ternos masculinos fosse reduzida a cerca de $26 \%$, definindo assim o terno zoot como um artigo ilegal, antipatriótico (POLHEMUS, 1994). A proibição da silhueta larga não foi suficiente para tirar das ruas esse estilo. Quanto mais os zooties eram criticados, mais jovens sonhavam em possuir um (BOLLON, 1993). No entanto, essa insubordinação não conseguiu se livrar da intolerância de alguns grupos que se autoproclamavam "patriotas". A partir de 1943 uma série de ataques foi dirigida àqueles que se aventuravam a utilizar o terno subversivo. Ted Polhemus (1994) destaca que algumas gangues formadas por jovens brancos, no sul da Califórnia, atacavam jovens negros que estivessem vestidos "fora dos padrões" deixando-os na rua sem roupa alguma. Polhemus acrescenta que é "neste momento de repressão que o terno zoot se transforma em um objeto de identidade para os negros, uma vez que se torna um uniforme, no sentido pleno da palavra, um distintivo de desafio, um marcador da comunidade e uma declaração ideológica"” (POLHEMUS, 1994, p. 19). Essa subversão acabou servindo de prenúncio para os tempos que estavam por vir.

\section{Um estilo em formação}

A partir de 1960, o corpo dos jovens se transformou em uma ferramenta fundamental para a criação e a aplicação de ideias que iam de encontro à filosofia de seus pais e avós. Emancipação sexual, liberdade para as mulheres, combater guerras e reivindicar a igualdade racial eram algumas das plataformas de luta naquele momento. De acordo com Hobsbawm (1995), a destruição do passado, compreendido como um mecanismo social que vincula nossas experiências pessoais à das gerações anteriores, é uma das características principais do século XX, em especial da década supracitada. No contexto da luta pelos direitos civis no período, a moda foi um importante objeto na construção de uma identidade própria para os negros. Naquele estágio, buscava-se negar a supremacia da cultura europeia que havia mutilado os continentes americano e africano em busca de riqueza e poder. Os padrões do colonizador e do explorador precisavam ser superados, pois não expressavam os interesses das minorias que conduziam a aspiração por mudança. Segundo Pinho (2004), na maior

\footnotetext{
${ }^{4}$ Tradução minha para: To wear a zoot in 1943 was top put yourself on the line and within this context the garment became a uniform in the full sense of the word - a badge of defiance, a marker of community and an ideological statement.
} 
parte das colônias americanas, que receberam escravizados africanos, foi inserida a ideia de que os negros eram feios. A autora aponta que a cor escura da pele, em contraste com a aparência do branco europeu, era associada à sujeira, à impureza de uma alma já condenada aos piores destinos.

\begin{abstract}
Para complementar a suposta feiura da cor, os cabelos crespos e os traços grossos revelariam a falta de refinamento e a agressividade do negro, já que as representações acerca do fenótipo denotariam características da índole ou dos "dons naturais". (PINHO, 2004, p. 111)
\end{abstract}

O corpo negro recebeu as piores denominações possíveis. Muitos senhores de escravizados, que os usavam para todo o tipo de transporte, associaram a imagem do negro com o mau cheiro e a sujeira. Anos de dominação acabaram estigmatizando a aparência do negro que, mesmo após a abolição, precisava se esforçar para "melhorar a forma como se apresentava em público" (PINHO, 2004, p. 111). A parte do corpo negro que melhor representa a contradição de possuir uma estética que não se encaixa no mundo é o cabelo. Ao rejeitar o fio crespo e adotar o padrão "liso europeu", o afro-americano buscava uma inserção social ao mesmo tempo que via sua autoestima abalada, pois a imagem sonhada, nunca era alcançada. Por maiores que fossem os esforços e as manipulações químicas, aquilo que se via no espelho ia de encontro com tudo o que a mídia propagava, defendia e vendia. É por isso que uma mudança na relação do negro com seus cabelos foi de extrema importância para que eles se aceitassem e acabou se tornando pauta dos movimentos que lutavam pela afirmação dessa comunidade.

Se antes os homens utilizavam cortes bem curtos e as mulheres negras buscavam se pentear como as brancas, muitas vezes alisando seus cabelos, a partir da afirmação de suas identidades elas passam a assumir o formato natural dos cachos. A naturalidade, aliás, é associada à origem africana, que é a inspiração para a adoção de novos elementos de identificação. Essa forma de se apresentar demonstrou uma força tão grande que o penteado ganhou o nome do próprio movimento: black power ${ }^{6}$. Ainda que na contemporaneidade este termo seja unicamente utilizado para a definição dos cabelos crespos, essa não foi a única manifestação estética da ideologia. A tendência étnica também foi uma grande aliada na construção de um discurso próprio de afirmação. Defender o ideal “Black

\footnotetext{
Pinho (2004) ressalta em sua pesquisa que na contemporaneidade os negros ainda são julgados por sua aparência. A autora argumenta que, não muito raro, jovens negros são abordados por possuir uma "aparência suspeita".

“O termo "black power" teria surgido por volta de 1966, o ano em foi utilizado pela primeira vez em público. Após ser detido pela vigésima sétima vez, o estudante e ativista Stokely Carmichael teria gritado em um protesto que a única solução para a segregação seria a reivindicação de um poder negro (black power), que todos aqueles que sofriam pela segregação deveriam tomar para si a luta e brigar pela construção de uma nova sociedade.
} 
is beautiful" significava a busca de uma origem pura, resgatando traços que se perderam nas mãos do colonizador.

Assumir que ser negro é bonito era assumir um orgulho da própria cor, do passado e dos ancestrais. Para transmitir essa mensagem, muitos jovens negros retornaram à África para adquirir uma inspiração que resgatasse e identificasse a liberdade de seu povo. As cores vibrantes e os tecidos coloridos foram os elementos escolhidos para a implantação dessa ideia. As batas, que no continente africano possuem o poder de identificar a posição social, política e religiosa dos indivíduos, foram transportadas para o Ocidente como exemplar de beleza e orgulho das origens. Adquirindo um novo significado, elas se tornaram símbolo da identidade afro-americana.

Essa modificação da percepção do negro a respeito do próprio corpo se insere em um contexto histórico bem específico no processo de construção de sua identidade. 0 chamado "Movimento pelos Direitos Civis" é a expressão mais singular da contestação de valores e ideias que relegavam ao negro um papel de submissão na sociedade norte-americana. Nascido em meados da década de 1950, esse movimento lutava contra o sistema de segregação racial que, sobretudo na região do sul dos Estados Unidos, julgava os afro-americanos inferiores e os privavam até mesmo da utilização de espaços públicos. A principal estratégia do grupo era não se valer da violência para expor seu ponto de vista e defender seus direitos. Seu principal expoente, o pastor Martin Luther King, defendia a desobediência civil (o não cumprimento de regras segregacionistas impostas pelos brancos preconceituosos) como caminho para alcançar a liberdade e a igualdade entre todos.

A repercussão dos primeiros protestos serviu de inspiração para a criação de novas manifestações, como as dos Panteras Negras. Fundado em 1966, os Panteras se organizavam em um partido que pretendia defender, por meio da força, o direito dos negros americanos. Cansados das perseguições, das prisões sem motivo e do puro preconceito da sociedade norte-americana esses manifestantes não viam outra solução a não ser utilizar armas para reagir à opressão. Com uma doutrina inspirada nos ideais marxistas, os Panteras Negras radicalizaram o discurso, atuando em diversas áreas, em uma busca incansável pela atenção de todos: protestos em locais públicos, passeatas e aparições armadas em bairros periféricos, que se transformavam em confronto direto com autoridades policiais, e até mesmo o oferecimento de ajuda material a comunidades negras mais pobres, agitaram o fim da década de 1960.

O movimento político dos Panteras Negras possuía, além de uma filosofia única, uma forma própria de identificação por meio do vestuário. As calças confeccionadas em jeans já eram comuns entre a juventude contestadora e conferiam a mobilidade necessária para os previstos confrontos com os policiais. 0 casaco na cor preta, geralmente feito em couro, possuía bolsos, artefatos utilitários para quem não podia carregar uma bolsa. Compunham ainda o visual a boina (retirada do signo militar) e as luvas negras, como podemos observar na figura 4. Esses eram os trajes revolucionários de quem estava pronto para o enfrentamento em defesa de seus ideais a qualquer preço. 
FIGURA 4 - PANTERAS NEGRAS DURANTE A DÉCADA DE 1960 NOS EUA

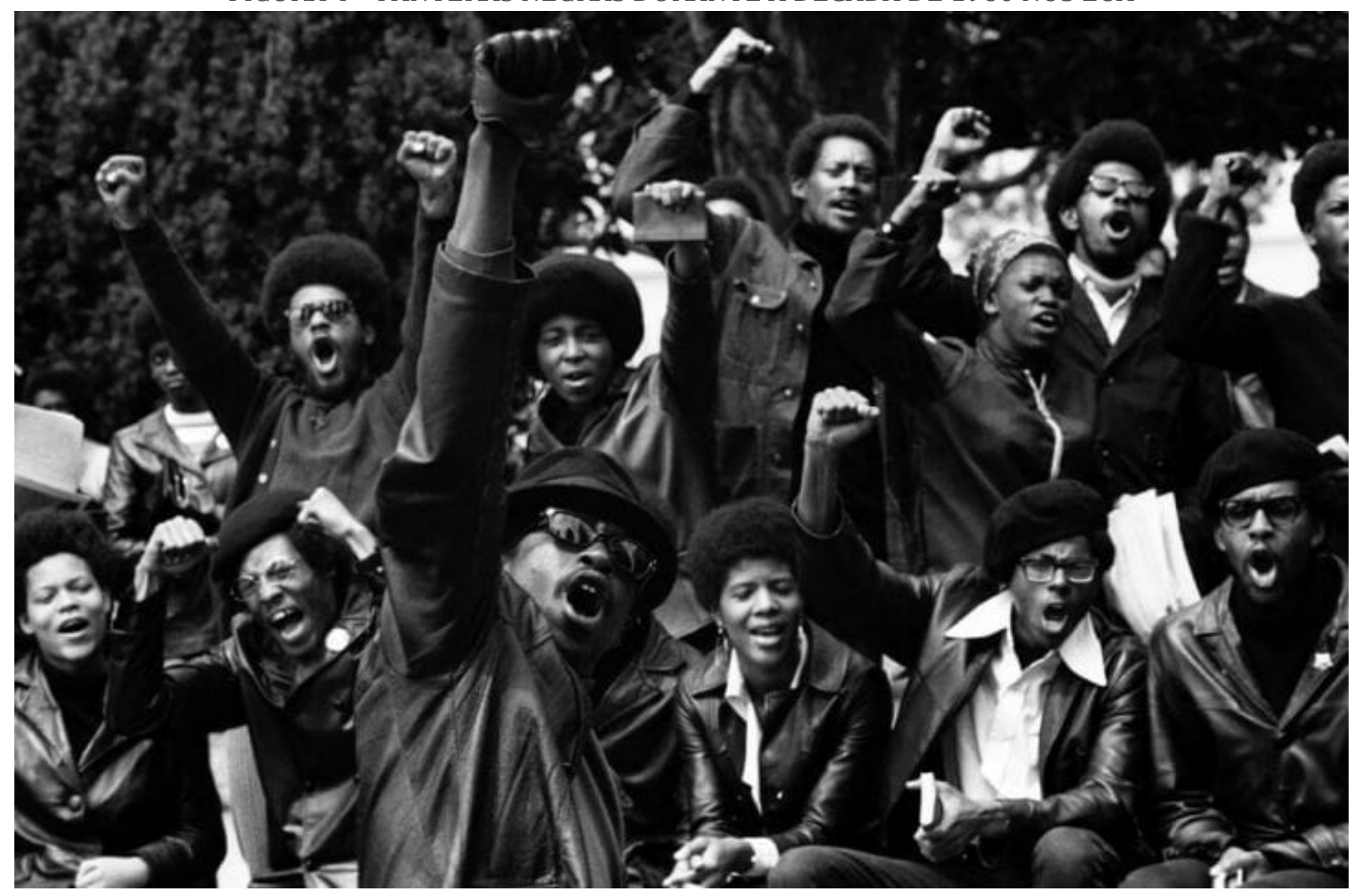

FONTE: Disponível em: https://www.hypeness.com.br/2018/10/fotos-raras-mostram-o-dia-a-dia-dospanteras-negras-nos-anos-1960-e-1970/. Acesso em: 25 jun. 2020.

\section{0 nascimento da moda black}

O cenário político agitado pelos movimentos de afirmação dos negros teve uma influência direta nas manifestações musicais produzidas por esse grupo no período. Ainda na década de 1960 a música negra norte-americana, cada vez mais aceita por outros extratos sociais, ganha uma nova vertente conhecida como soul. As origens do soul encontram-se ligadas (assim como as do jazz) ao hibridismo entre a cultura do colonizador e a vivência trazida pelo africano do seu continente e de seus antepassados. Nesse caso específico, o ritmo é derivado da mistura da música gospel estadunidense com a profana, representada pelo estilo R\&B. A ideia era resgatar a verdadeira música negra, atingir a alma, corrompida pelo contato com a indústria cultural branca e que, naquele momento, já não mais representava a classe de guerreiros que batalhava pela igualdade civil.

O soul é responsável por expandir a imagem do negro feliz com a sua aparência e, na década de 1970, tornou-se sinônimo de uma forma distinta dele se colocar socialmente em seus momentos de lazer. A preocupação em se vestir bem, se pentear bem, se apresentar bem, tal qual os antepassados do século XIX, não havia desaparecido. A questão era acrescentar novos símbolos que auxiliassem no processo de autoafirmação. Assim, as rou- 
pas eram muito coloridas, óculos e chapéus eram exagerados, ternos, casacos, gravatas, tudo fazia menção ao excesso, incluindo os sapatos em estilo plataforma. Ainda que muitos militantes afro-americanos tenham protestado contra, a soul music foi rapidamente assimilada pelo mercado fonográfico, assim como a indumentária ligada ao estilo musical, que se tornou uma das principais referências da moda nos anos 1970.

\section{FIGURA 5 - 0 ESTILO SOUL EM FOTOGRAFIA DE 1970}

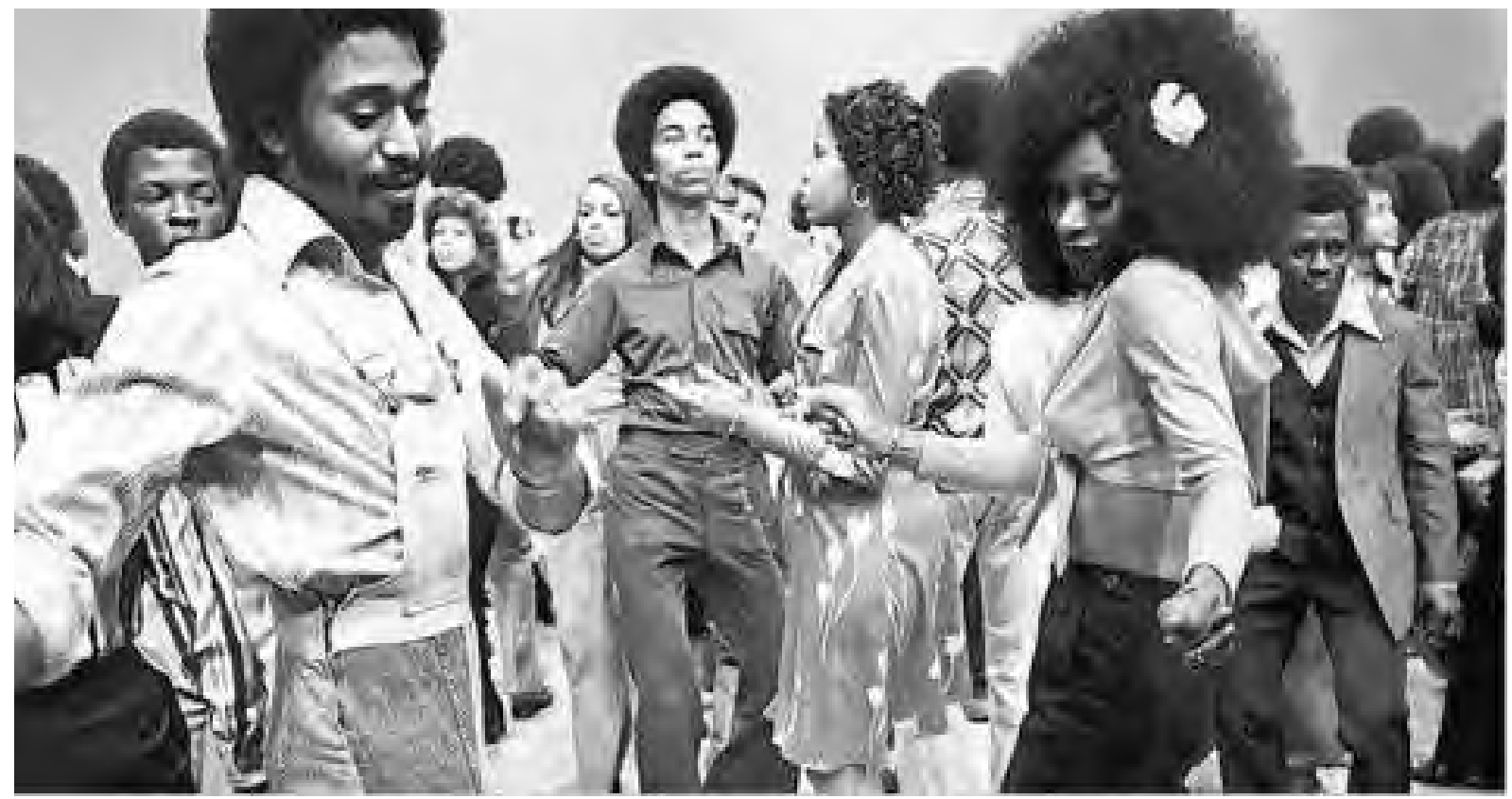

FONTE: Disponível em: http://darkjive.com/tag/soul-train/. Acesso em: 20 mar. 2015.

A dança é um elemento muito importante para aqueles que aderiram ao estilo soul. Ribeiro (2008) destaca que a dança soul privilegiava a elegância nos gestos e o relacionamento com o outro, fosse homem ou mulher. 0 momento reservado à dança nos bailes representa a consagração do indivíduo que consegue se destacar dos demais, garantindo a confiança e o respeito do grupo. 0 espaço da dança é também um espaço social, no qual o orgulho de ser negro era manifestado. Segundo Hermano Vianna (1987) em 1968 o soul havia sido incorporado pela indústria musical e já não possuía sua vertente revolucionária característica dos tempos em que as lutas negras por afirmação eram mais intensas. Ao serem assimiladas pelo mercado fonográfico, as canções soul, para muitos negros, já não eram mais a expressão de seus sentimentos.

Assim, em busca de uma autenticidade musical, uma variação do soul surge na virada da década de1960 para a de 1970. 0 chamado funky, ou funk, emerge nos subúrbios norte-americanos para simbolizar o orgulho negro. A palavra funk possui múltiplos significados ao longo da história do afro-americano. Polhemus (1994) descreve que, no século XVII, o termo fazia referência ao odor dos escravos. Já durante a década de 1920, muitos músicos ligados ao jazz utilizavam a palavra para designar os aromas característicos da prática sexual. Ao longo dos anos 1950, 1960 e 1970, os negros continuaram utilizando-a com conotação se- 
xual, dessa vez ressaltando sua superioridade em relação aos brancos nesse quesito. 0 fato é que o sentido negativo ganhou um novo significado, e, de acordo no Herschmann (2000), passou também a identificar uma vertente da música negra novamente revolucionária, com ritmos mais marcados e arranjos mais agressivos. Vianna (1987) acrescenta que, nesta época, anos 1970, o termo funk podia ser utilizado em tudo: um jeito de andar, uma rua, um bairro, uma dança e, é claro, uma roupa. Ted Polhemus (1994) descreve o estilo funk como uma abordagem sensual na maneira de se vestir. Buscando inspiração nos ternos zoot, as calças masculinas tinham a cintura alta e possuíam um ajuste apertado em torno da virilha e na parte inferior. Ao mesmo tempo, utilizava-se materiais caros, como a camurça e a pele de cobra. Completavam o visual o chapéu, os suspensórios e os cintos e as correntes dourados, como podemos observar na figura 6 .

\section{FIGURA 6 - Grupo GRUPO P - FUNK NA DÉCADA DE 1970}

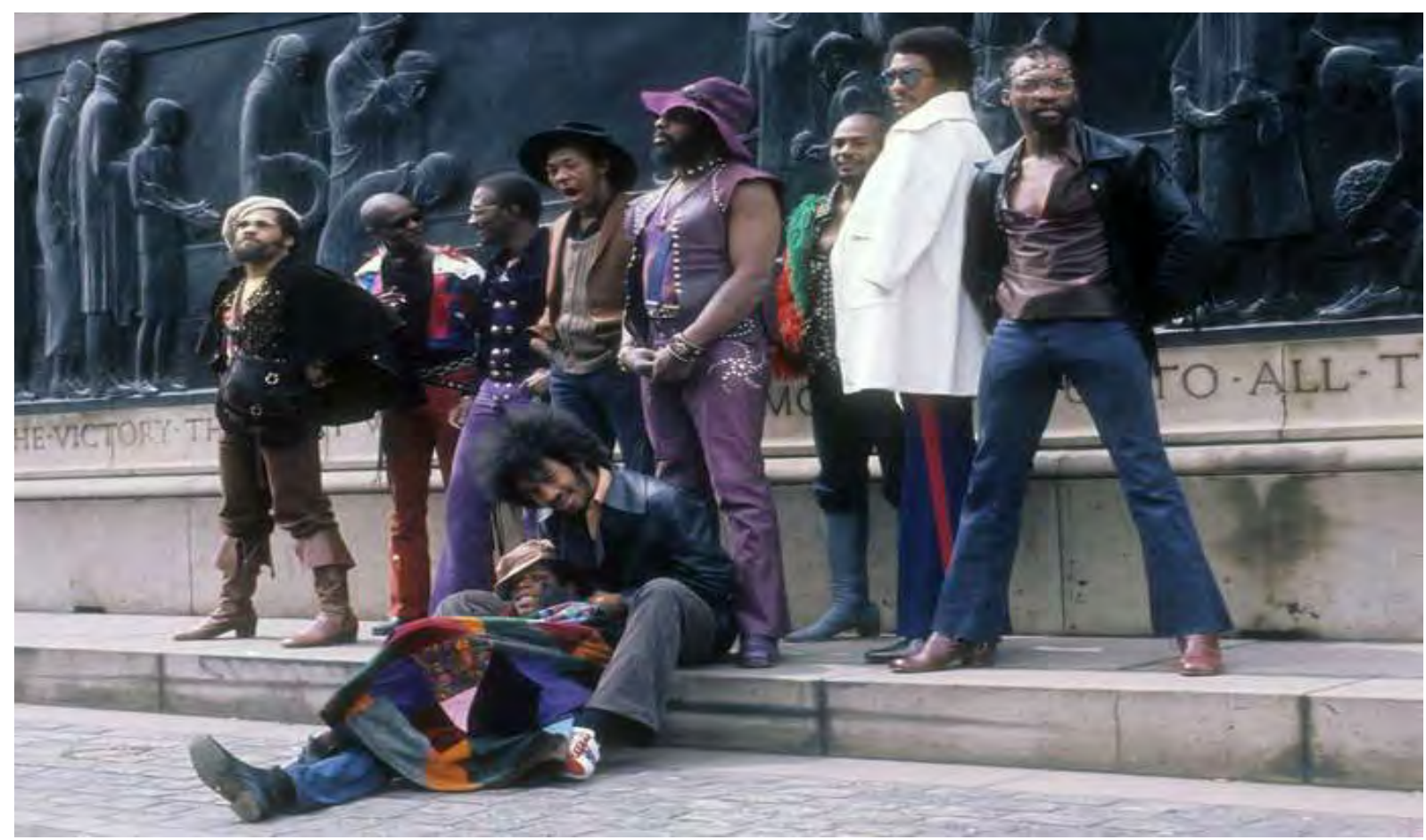

FONTE: Disponível em: https://www.britannica.com/topic/Parliament-Funkadelic. Acesso em: 3 mar. 2020.

Em seu trabalho sobre estilos urbanos, Polhemus (1994) destaca que, no início da década de 1970, os meios de comunicação das elites brancas estavam ainda maravilhados com a revolução da cultura hippie e, desse modo, demoraram para perceber as peculiaridades da indumentária funk. Naquele momento, surgia um novo estilo, o black. A partir da adoção pelos negros de determinados signos visuais, a moda transformava-se em um instrumento de protesto contra uma sociedade discriminatória, que precisava com urgência ser combatida. Era uma maneira eficiente de contestar as práticas que segregavam e asseguravam a manutenção do racismo na sociedade estadunidense. Uma forma de comunicação que conseguia ultrapassar as barreiras linguísticas e possíveis censuras e repressões. Em última instância, 
a adoção pelos afrodescendentes de sua imagem, valorizando seus traços naturais, também foi importante para demarcar um sentimento de pertencimento e autoestima do grupo. A estética e a beleza provocam sentimentos e emoções que levam a empatia e a construção de valores comuns. Pela primeira vez os negros sentiam-se orgulhosos de sua cor, de seu cabelo, de seu estilo. Uma experiência que foi essencial para a solidificação da cultura negra no cenário mundial.

\section{A moda hip hop}

Os anos 1970 foram muito complicados no plano socioeconômico, marcados por uma grave crise no mundo capitalista. O historiador Eric Hobsbawm (1995) destaca que embora países desenvolvidos economicamente, como os Estados Unidos, não admitissem, naquele momento estava ocorrendo um verdadeiro desmoronamento da ideologia da prosperidade e da riqueza construída nas décadas anteriores. Esse panorama acabou por atingir em cheio aqueles que estavam mais vulneráveis a uma crise econômica: imigrantes vindos de países latino-americanos e, sobretudo, a população negra. Fragilizada após anos de restrições, uma boa parcela desse grupo residia nas áreas periféricas das cidades, onde vivia sob condições precárias, submetida a uma alimentação deficiente e, a um acesso limitado aos níveis superiores de educação e aos empregos que lhes oferecia uma remuneração abaixo do que era necessário para viver dignamente e adquirir perspectivas de crescimento profissional.

É nesse contexto que o hip hop surge nos Estados Unidos. Em sua investigação sobre o tema, Micael Herschmann (2000) enfatiza que o hip hop aparece como um forte referencial que permitiu a conformação de identidades alternativas e de consagração para os mais jovens, em um momento que os antigos bairros e instituições locais (onde eles encontravam a sua identificação) estavam sendo destituídos. Sintetizando uma nova forma de contestação da realidade pela comunidade negra, o movimento exibia à sociedade toda a condição subalterna que era reservada aos negros. Compartilhando uma experiência de sofrimento em comum, os afro-americanos tinham a consciência da inexistência de ações governamentais que se dedicassem a observar e a auxiliar na resolução dos seus problemas e acreditavam que foram os próprios órgãos de poder que os submeteram a essa condição. A partir dessa identificação de aspirações em comum, uma nova subcultura ${ }^{7}$ urbana surgirá, representando-se por meio de uma linguagem própria que inclui música, dança, moda e arte.

O hip hop é composto por três expressões básicas: o rap, o break e o grafite. Em linhas gerais, podemos definir o rap como a manifestação musical, o break sendo o estilo de dança e o grafite representando a identidade visual do movimento. 0 rap surge em terras norte-americanas no início da década de 1970, organizado por jamaicanos que procuravam melhores condições de vida e trabalho. Em busca do "sonho americano", esses imigrantes chegavam à região do Bronx, em Nova Yorque, levando seus hábitos culturais. Em sua terra

\footnotetext{
Subcultura é compreendida neste trabalho de acordo com o pensamento de Clarke, Hall, Jefferson e Roberts, (1976) que define o termo como uma manifestação cultural particular, resultado de uma subdivisão de uma cultura dominante, mas que representa as aspirações de uma classe social distinta.
} 
natal os jamaicanos estavam acostumados a se expressar pelo toasting, uma forma musical na qual frases improvisadas eram colocadas sobre uma mixagem feita a partir de suas músicas preferidas. É importante ponderar que desde o período escravista há relatos de afro-americanos criando versos que expunham seus sentimentos e pensamentos enquanto trabalhavam ou manifestavam sua religião. A própria memória do povo africano é muito ligada à fala e aos versos, uma vez que a passagem dos costumes entre as gerações desse continente sempre foi por meio da oralidade, tendo a escrita adquirido importância bem tardiamente. 0 rap encontra-se intimamente ligado à fusão de tradições e novas leituras musicais que irão se encontrar com a tecnologia disponível em seu período de gestação.

Os primeiros temas abordados pelo canto rap foram as desigualdades sociais e o racismo presentes na sociedade norte-americana. As experiências pessoais ofereciam o material para que esses "trovadores contemporâneos" pudessem elaborar uma poesia urbana que rapidamente ganhou a simpatia daqueles que se identificavam com o que estavam ouvindo. Não havia fronteiras para o rap, bastava apenas apresentar criatividade e originalidade, que todos os assuntos podiam ser transformados em obras artísticas. Diferentemente de outros estilos musicais, que exigem do compositor um conhecimento apurado em instrumentos musicais, o rap era acessível mesmo àqueles que nunca haviam adquirido uma educação musical em suas vidas. Extremamente democrático, para rimar não era preciso ter dinheiro ou elaborados equipamentos musicais, esse novo estilo oferecia a todos a possibilidade de integração.

As roupas possuem um significado importante para aqueles que apreciam o hip hop. As vestimentas assumiram, ao longo do desenvolvimento do estilo, um papel importante na caracterização de seus apreciadores, tornando-se um símbolo de sua ideologia, servindo também como forma de expressão e posicionamento social. A pesquisadora norte-americana Elena Romero (2012), ao entrevistar os primeiros adeptos do movimento, percebe que a preocupação com a maneira de se vestir permeava a ideologia e as relações sociais dentro do grupo.

Os caras que se vestiam melhor conquistavam mais atenção e mais garotas. E se um cara fazia parte de uma equipe, além de estar bem vestido também estivesse fazendo música, ainda mais atenção apareceria em seu caminho ${ }^{8}$. (ROMERO, 2012, p. 11)

Romero (2012) também destaca que a importância da moda para o universo hip hop está muito além da simples busca pela diferenciação de jovens habitantes das periferias urbanas. Segundo a autora, a criação de um estilo próprio ligado ao hip hop representou a emancipação dos negros em sua maneira de se vestir, pois, a partir de então, a indústria da moda se viu obrigada a voltar sua atenção para eles, enxergando-os como consumidores específicos.

8 Tradução minha para: The guys who dressed the best got the girls and attention. And if a guy was part of a crew that was doing music in addition to being best dressed, even more attention came his way. 


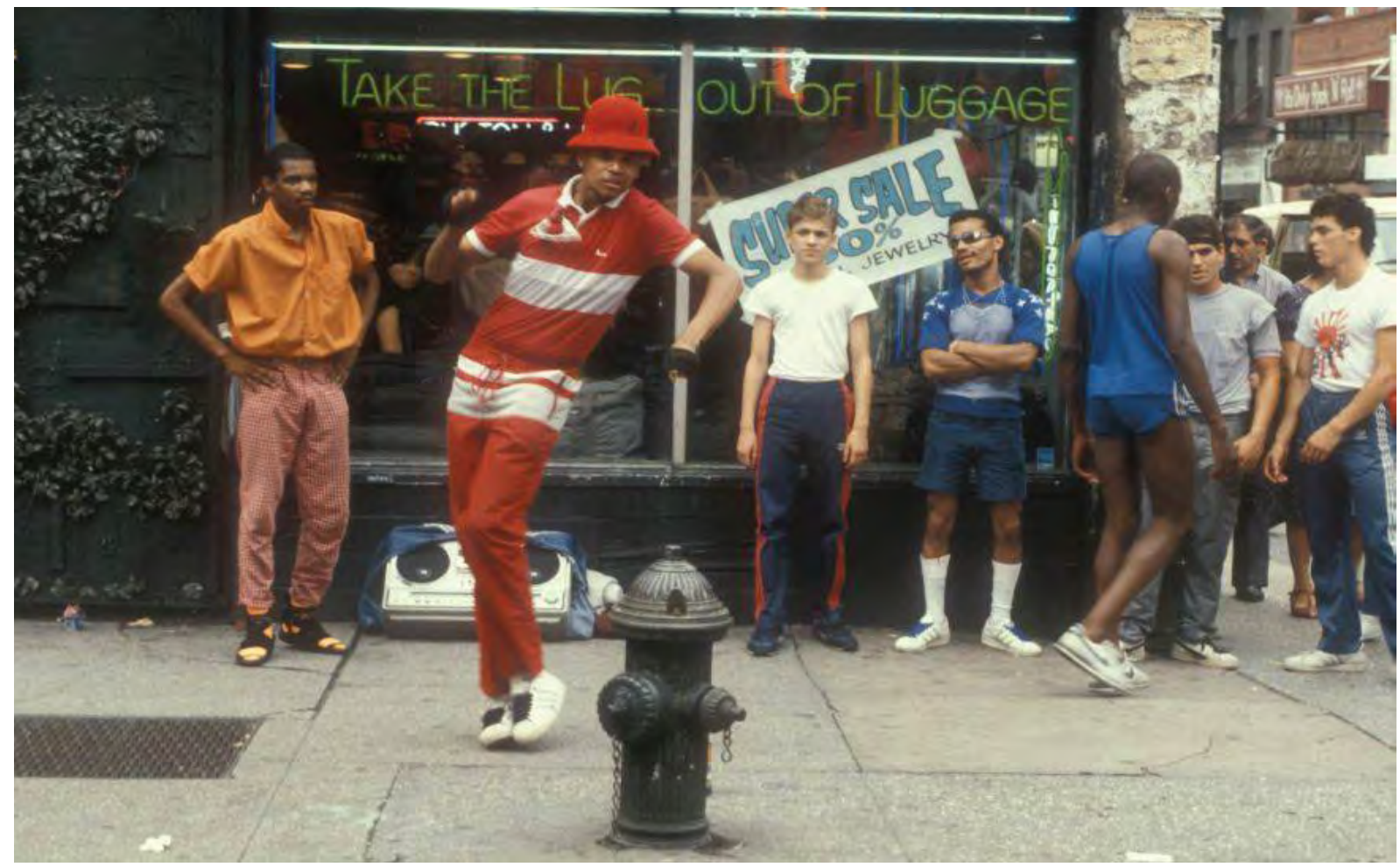

FONTE: Disponível em: https://allthatsinteresting.com/hip-hop-origins\#2. Acesso em: 5 mar. 2020.

Sue Van der Hook (2010) destaca que a moda ligada ao hip hop não é fruto da criação de estúdios especializados, ou idealizada por grandes mentes criativas. Pelo contrário, ela se inicia paralela ao movimento do fim dos anos 1970, nas ruas do Bronx em Nova Yorque, de forma espontânea e sem controle. Nesse período, a escolha da indumentária se ligava muito à participação de cada indivíduo possuía no movimento. Para os dançarinos de break, a performance era o que conferia status entre o grupo, por isso as roupas escolhidas para as apresentações eram as de estilo atlético, que facilitavam a mobilidade e os identificavam em seu meio. Calças que remetiam a uniformes de equipes esportivas e camisetas justas eram os elementos mais utilizados. Além desses itens, recebiam também uma atenção especial os bonés que distinguiam e protegiam as cabeças durante as performances de dança no solo (POLHEMUS, 1994).

Os aspectos visuais adotados pelos membros da subcultura hip hop foram essenciais para que ela conquistasse visibilidade e atraísse a atenção de novos apreciadores. Nesse sentido, a mídia desempenhou um papel fundamental para que o hip hop ganhasse os Estados Unidos e se espalhasse também pelo mundo. Ao tentarmos compreender a relação do movimento hip hop com os veículos midiáticos, percebemos que ela é pautada em controvérsias, situada entre a dependência e a repulsão. De fato, como em todas as subculturas juvenis desenvolvidas ao longo da segunda metade do século XX, os meios de comunicação foram essenciais para a divulgação das ideias e dos pensamentos daqueles que ousavam 
contrariar as rígidas regras da sociedade e manifestar suas vontades, transmitindo seus valores ou os encaixando na categoria da subversão, criminalizando os membros dessas manifestações juvenis.

Em meados dos anos 1980, o hip hop era descrito com muitas reservas pelos meios midiáticos. Eles, enxergavam os elementos característicos da subcultura como exemplares perigosos de uma rebeldia da periferia. 0 fato é que as canções eram consideradas agressivas demais e, por isso, não comerciais. Mesmo com a relutância da mídia em reconhecer os valores do rap, com o Run DMC, o estilo ganhava cada vez mais apreciadores. Em 1986, o grupo inovaria novamente ao conseguir ingressar no lucrativo mercado do vestuário. 0 Run DMC sempre utilizava em suas exibições tênis da grife Adidas sem o cadarço, sendo imitados por inúmeros jovens que os admiravam e seguiam. 0 sapato se transformou em uma espécie de marca, um signo próprio do grupo de rap, tão importante que mereceu dos mesmos uma homenagem na música My Adidas. Na canção, os rappers dão um destaque à construção da própria trajetória e ressaltam que dos tempos difíceis ao estrelato, o tênis estava lá. Da época em que possuíam apenas um calçado ao auge, quando podiam adquirir um par de cada cor, o Adidas sempre esteve presente. Essa passagem é muito bem descrita por Klein:

O mais recente capítulo na corrida do ouro do mainstream americano para a pobreza começou em 1986, quando os rappers do Run DMC deram uma nova vida aos produtos da Adidas com seu sucesso My Adidas, uma homenagem à sua marca favorita. [...] depois ocorreu a Russel Simmons, presidente do selo Def Jam Records do Run DMC, que os rapazes deveriam ser pagos pela promoção que estavam fazendo para a Adidas. Ele abordou a empresa de calçados alemã sobre a possibilidade de destinar algum dinheiro para a turnê Together de 1987. Os executivos da Adidas foram céticos a respeito de se associar com a música rap, que na época era rejeitada como moda passageira ou difamada como incitação à baderna. Para ajudá-los a mudar de ideia Simmons levou dois mandachuvas da Adidas a um show do Run DMC [...] três mil pares de tênis foram atirados para o ar. Os executivos da Adidas sacaram seu talão de cheques com uma rapidez recorde. Durante a feira anual de calçados esportivos em Atlanta naquele ano, a Adidas revelou sua nova linha de calçados Run DMC: a Super Star e a Ultra Star- desenhados para ser usados sem cadarço (KLEIN citado por FOCCHI, 2006, p. 57).

A demonstração de adesão do segmento rap ao tênis Adidas levou os executivos da marca a repensar sua estratégia de vendas nos Estados Unidos. Até aquele momento, a empresa alemã estava em desvantagem no segmento, enfrentando a forte concorrência da Nike, que levava a preferência dos jovens estadunidenses, e da Reebok que dominava o mercado fitness. Com o Run DMC, a Adidas conseguia, enfim, estabelecer um público-alvo para seus produtos, podendo ampliar sua participação no mercado. 


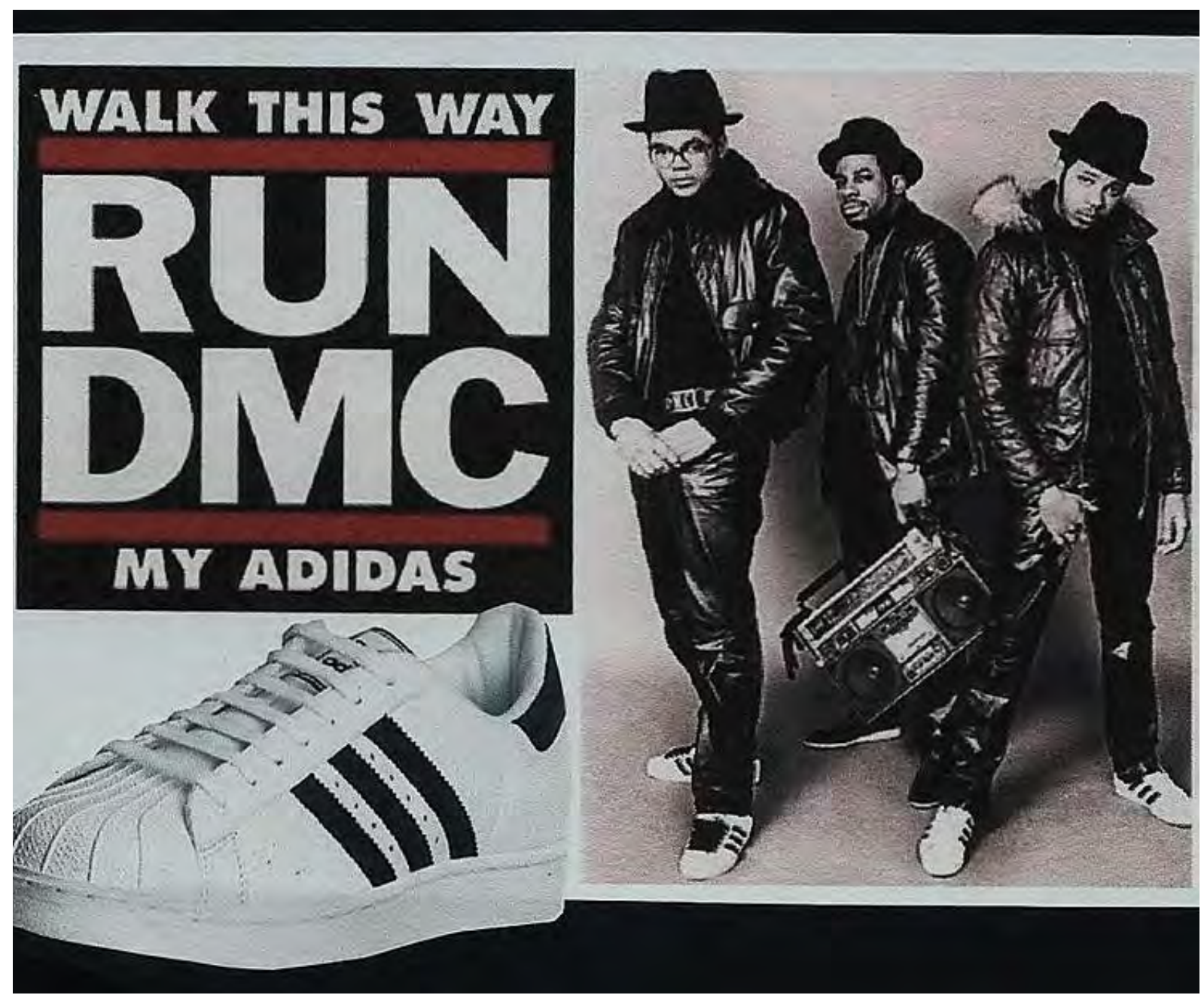

FONTE: Disponível em:http://forum.exotics4life.com/showthread.php?11147-VIDEO-RUN-DMC-feat-ATrak-Unite-All-Originals. Acesso em: 17 jan. 2015.

A parceria entre a Adidas e o Run DMC foi significativa para que a moda hip hop superasse as fronteiras da periferia e conseguisse se tornar um exemplar da cultura urbana. Era a primeira vez que personalidades que não eram ligadas à área esportiva faziam propaganda de um tênis (ROMERO, 2012), o hip hop mostrava sua força junto ao público juvenil estadunidese. Aos poucos, itens típicos do vestuário de b. boys e rappers eram vistos nas ruas de todo o país. Seja a jaqueta bomber ${ }^{9}$, seja o tênis esportivo, seja um label-festooned

\footnotetext{
As jaquetas bomber têm sua origem no exército estadunidense e possuem como característica o corte pela cintura e abertura frontal, normalmente fechadas com elásticos na cintura e nos punhos para não deixar o frio entrar.
} 
hooded sports- top ${ }^{10}$, todos utilizavam algum elemento ligado ao mundo hip hop. Ao mesmo tempo em que a música se tornava conhecida, as roupas passaram a ser objeto de desejo e consumo (HOOK, 2010).

A popularização levou aqueles que se identificavam com a ideologia do movimento a criar códigos para se diferenciar de quem fazia compras somente pela notoriedade do estilo (POLHEMUS, 1994). Os reais membros da subcultura precisavam de uma nova maneira para aproximar aqueles que conheciam a ideologia e afastar os que apenas os imitavam, sem o real conhecimento da mesma. É nesse contexto que subgrupos passam a existir de uma maneira mais visível dentro do hip hop. Enquanto alguns membros irão escolher diferentes marcas esportivas como suas preferidas, outros rappers buscam outras formas de representação. Ted Polhemus destaca a atuação do grupo Public Enemy que começa a valorizar, em suas vestimentas, características como o preto, as estampas camufladas e os grandes casacos que elevavam a indumentária do movimento a uma categoria mais combativa, ao mesmo tempo que buscava inspiração na própria história do povo afro-americano. Segundo Leal, a importância do Public Enemy, reside no fato desse grupo levar para o rap um conteúdo mais politizado, ligado à história do negro nos Estados Unidos, o que elevava o rap a um novo estágio, relacionado à cultura e ao conhecimento.

Em meio à mesmice que dominava o rap, surge em Nova York, em socorro não apenas ao hip hop, mas à toda América negra, o Public Enemy. Inspirado na luta dos líderes Martin Luther King, Malcolm X e de grupos ativistas como os Panteras Negras, o Public Enemy traz uma mensagem politizada ao povo afro-americano em seu primeiro álbum Yo! Bum rush the show. Vestimentas africanas se misturam ao visual pesado do gueto e medalhões artesanais com os desenhos do continente africano gravado (conhecidos como zulu) assumem o lugar das pesadas correntes de ouro. Pode-se dizer que, nesse momento, o rap torna-se de fato a trilha sonora da resistência negra nos EUA. (LEAL, 2007, p. 88)

Podemos perceber na figura 9 que o Public Enemy adota um vestuário que acompanha a filosofia de enfrentamento do grupo à mídia americana e à sociedade que ainda discriminava a população negra. Chama atenção a utilização de grandes relógios pendurados no pescoço em vez das correntes usadas pelo Run DMC. A postura adotada pelo P.E. não condizia com a utilização de joias ou artefatos que os ligasse ao luxo do sistema capitalista que tanto criticavam.

10 Casaco em moletom com capuz e bolsos frontais, exibindo um bordado da marca. 


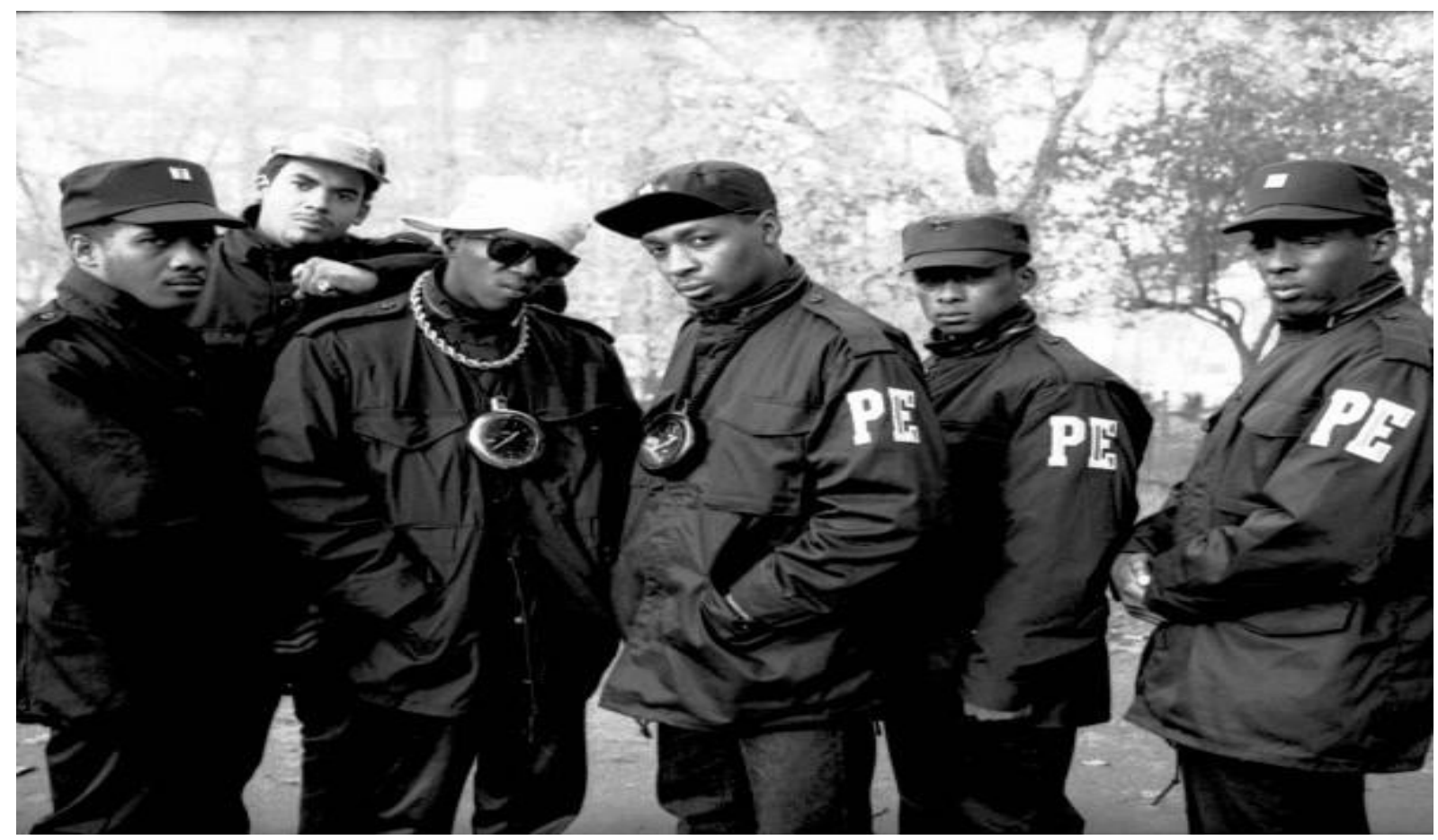

FONTE: Disponível em: http://images.frompo.com/4656b9af10eba4ad83b71467d56752dc. Acesso em: 20 mar. 2015.

Sue Vander Hook (2010), em seu estudo sobre as principais características da moda hip hop, destaca que não importava a maneira como se expressavam, os hip hoppers usavam a roupa para quebrar paradigmas e se firmar tanto no mercado fonográfico quanto na sociedade. A vestimenta era utilizada como um mecanismo para chamar a atenção de todos para a emergência dessa nova manifestação jovem. Um exemplo dessa espécie única de utilização da roupa como fonte de significado foi a incorporação na indumentária das calças saggy no início dos anos 1990. As saggy jeans são calças largas, adquiridas um ou dois números a mais que o necessário por seus usuários. Elas foram adotadas pelos rappers em alusão aos uniformes penitenciários que, pela padronização, muitas vezes são em tamanho maior do que o utilizado pelos detentos. A impossibilidade de usar cintos (para que acidentes fossem evitados) fazia com que as calças caíssem, mostrando parte da roupa íntima. Ao saírem da prisão, muitos ex-detentos continuavam utilizando esse tipo de calça, como uma espécie de respeito pelo seu passado no território em que conviviam. A aproximação de alguns rappers com esse universo elevou a saggy jeans para o "guarda-roupas do estilo". 


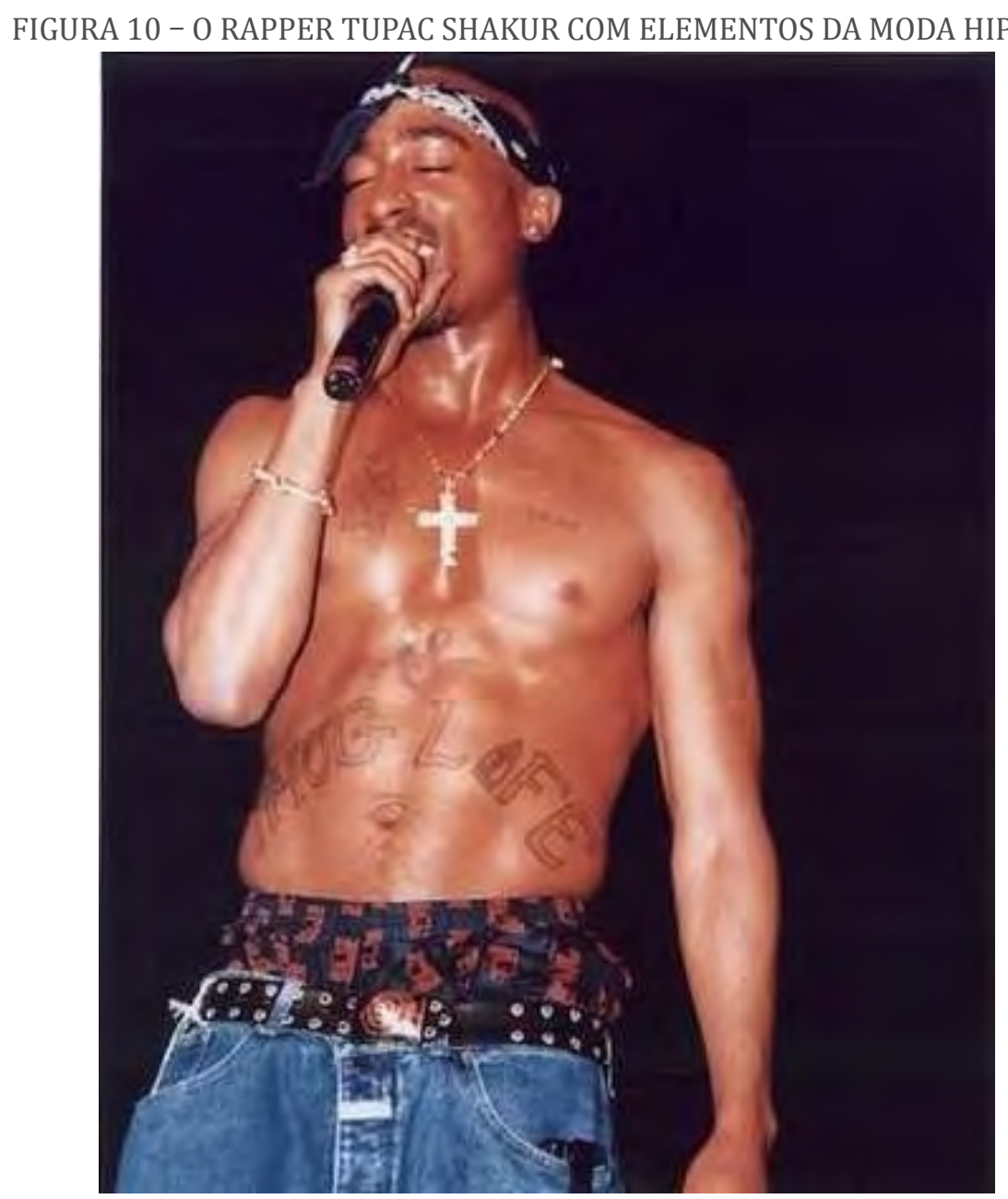

FONTE: Disponível em: http://pt.wikipedia.org/wiki/Tupac_Shakur. Acesso em: 1 abr. 2015.

A silhueta exagerada era, muitas vezes, combinada com acessórios esportivos, como os bonés de beisebol, usados em geral com a aba para trás (STEVENSON, 2012). Também compõem o visual oversize peças que fazem parte do uniforme de jogadores de basquete, principalmente camisas. Esse esporte é muito popular nas periferias estadunidenses graças à existência de quadras populares e ao baixo custo para a sua prática. Por isso, os grandes destaques do esporte em nível nacional são oriundos dessas comunidades, tendo convivido de perto com o mesmo universo que deu origem ao hip hop. Assim, ocorreu um verdadeiro intercâmbio de influências entre o esporte e a subcultura: rappers usavam itens de atletas do basquete e atletas se vestiam com signos do hip hop.

A fama adquirida por meio da divulgação em massa das músicas, proporcionou à juventude que se dedicava ao rap uma ascensão financeira até então não experimentada. Mansões, carros exclusivos, festas e outros luxos que o dinheiro proporciona, passam a ser usufruídos e exibidos pelos rappers. Esse novo status econômico alcançado acabou se refletindo também na maneira como os músicos se vestiam. Assim, novas representações foram surgindo e novos signos incorporados. Trata-se da adoção de artefatos com valores 
simbólicos e econômicos ao visual de rappers, que passam a utilizar enormes cordões e pulseiras em ouro ou prata, muitas vezes cravejados de pedras preciosas. Os adeptos dessa significação ficaram conhecidos como Bling Bling ${ }^{11}$, ou simplesmente Bling, em referência ao barulho que as grossas correntes faziam ao bater uma na outra. A incorporação de joias não era exclusividade dessa vertente. Na realidade, desde os primórdios do rap, esses objetos já apareciam no visual de seus adeptos. 0 Bling consagra o exagero, o excesso.

FIGURA 11 - RAPPER JON LIL ÍCONE DO ESTILO BLING EM 2011

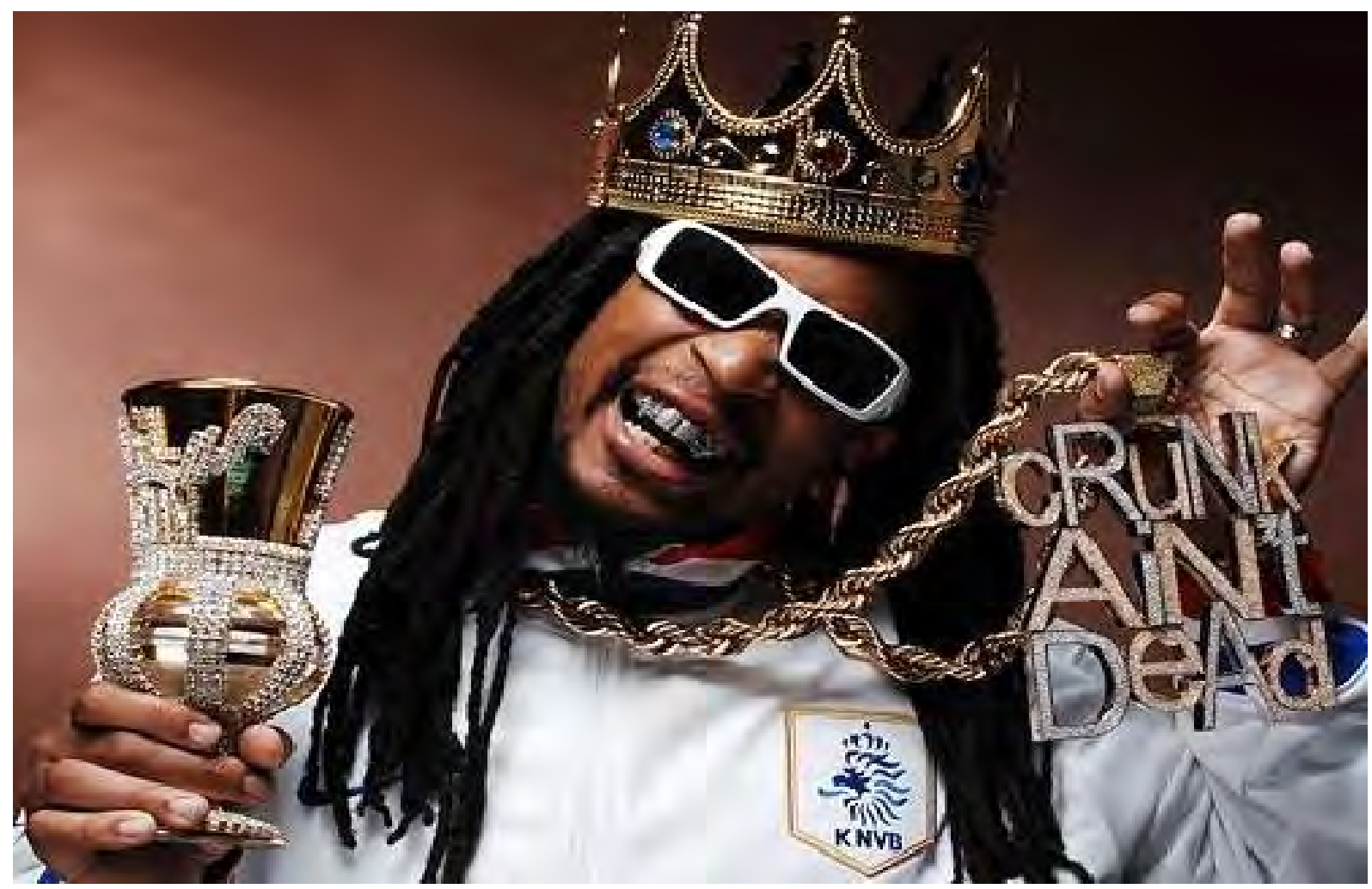

FONTE: Disponível em: http://www.thegroundmag.com/hip-hop-fashion/. Acesso em: 20 abr. 2015.

Para Hook (2010), a utilização das joias representa uma busca por individualidade já que, em sua forma, personificam um gosto por meio de uma forma representada, ou simplesmente trazem o nome de cada adepto da vertente. Nos anos 2000, alguns rappers passaram também a ostentar acessórios específicos em seus dentes. Os chamados Grillz são placas confeccionadas em metal ou pedras preciosas e se tornaram um acessório de moda, um verdadeiro símbolo de status (HOOK, 2010), marcando a era em que os rappers se transformaram em superestrelas, influentes em suas comunidades de origem e em outras áreas que antes os ignoravam.

11 De acordo com Hook (2010) esse termo foi utilizado pela primeira vez no fim dos anos 1990 pelos rappers Lil Wayne e B.G. em músicas que retratam o cenário de riqueza e poder adquirido pelos rappers. Em 2003 a palavra foi incluída no Dicionário Oxford. 
O sentimento de poder demonstrado, sobretudo pelos rappers no palco, representava tudo aquilo que a juventude afro-americana idealizava ser. 0 rap é responsável por divulgar um estilo de vida de sucesso, no qual o negro se destaca de forma positiva. Os rappers americanos foram responsáveis por introduzir uma nova relação entre as grifes de luxo e o mercado, celebrando, por meio de suas músicas e da indumentária um estilo de vida que até então não se identificava com uma população oriunda de locais economicamente desprivilegiados. Assim, os jovens das periferias começam a cobiçar essa posição favorecida, buscando formas de imitar a imagem dos rappers, principalmente no que tange a maneira de vestir. Elena Romero (2012) observa que a partir do momento que os artistas do gênero perceberam que eram influenciadores de tendências e que milhões de fãs os seguiriam, passaram a idealizar suas próprias marcas no ramo do vestuário.

\section{Considerações finais}

Ao longo deste trabalho procuramos apresentar a moda como item fundamental na formação da identidade do negro norte-americano. Percebemos que a escolha de um repertório próprio de roupas foi importante para a formação da identidade do grupo, servindo como fonte de distinção destes em relação a si mesmos e aos outros, fazendo com que uma parcela da juventude negra se reconhecesse como indivíduos, se orgulhasse de suas origens e construísse uma interpretação positiva a seu respeito.

A construção da identidade do jovem de descendência africana no contexto contemporâneo é resultado de um processo que transcende as questões raciais, uma vez que chama a atenção para a situação de desprestígio à qual milhares de pessoas estão submetidas nas periferias das grandes metrópoles do continente americano. Nesse sentido, a cultura musical construída pelos negros foi fundamental para que eles se reconhecessem como sujeitos, abrindo espaço nos meios midiáticos a fim de que os jovens pudessem se identificar com figuras que não mais reproduziriam os estereótipos negativos criados pela cultura dominante.

A instrumentalização do vestuário pelo afro-americano foi uma das estratégias de resistência à dominação e de inserção social desse grupo. Sabemos que o processo de construção das identidades é aberto, que toma novos significados e se reinventa continuamente. Por isso, sabemos que o hip hop não encerra esse fenômeno, embora faça parte de um novo momento do posicionamento social de uma juventude historicamente marginalizada. Além disso, estamos cientes da existência de outras manifestações juvenis no campo da moda e da música, datadas da mesma época histórica, que influenciaram o jovem negro e seu posicionamento social.

Por meio do intercâmbio cultural, característico da segunda metade do século XX, a música e a moda criada por negros norte-americanos foram divulgadas e influenciaram movimentos de afirmação por todo o continente. Nesse sentido, as roupas funcionaram como mediadoras de um sentimento de orgulho e de alteridade, fazendo com que o jovem afro-americano se identifique, chamando atenção para sua existência, suas demandas e suas reivindicações. 


\section{Referências}

BOULON, Patrice. A moral da máscara: merveilleux, zazous, dândis, punks, etc. Rio de Janeiro: Rocco, 1993.

CRANE, Diana. A moda e seu papel social. Classe, gênero e identidade das roupas. São Paulo: Editora Senac, 2006.

ERNER, Guilherme. Vítimas da moda?: como a criamos, por que a seguimos. São Paulo: Ed. Senac-SP, 2005.

FELIX, João Batista de Jesus. Hip hop: cultura e política no contexto paulistano. 2005. 206 p. Tese (Doutorado em Antropologia) - Universidade de São Paulo (USP), São Paulo, USP, 2005.

FOCHI, Marcos Alexandre Bazeia. Cultura hip hop e marcas alternativas: a presença da ideologia e das estratégias mercadológicas. 2006. 179 p. Dissertação (Mestrado em Comunicação e Mercado) - Faculdade Cásper Líbero, São Paulo, 2006.

GILMAN, Sander L. Black bodies, white bodies: toward an Iconography of female sexuality in late nineteenth-century art, medicine, and literature. In: Critical inquiry vol. 12, n. 1, p. 204242. Published by: The University of Chicago Press Article Stable. Disponível em: http:// www.jstor.org/stable/1343468. Acesso em: 10 dez. 2014.

GILROY, Paul. O Atlântico negro: modernidade e dupla consciência. Trad. Cid Knipel Moreira. São Paulo: Ed. 34; Rio de Janeiro: Universidade Cândido Mendes, Centro de Estudos Afro-asiáticos, 2001.

GIMENO, Patrícia Curi. Poética versão: a construção da periferia no rap. 2009. 169 p. Dissertação (Mestrado em Antropologia Social) - Universidade Estadual de Campinas (Unicamp), Campinas, 2009.

HALL, Stuart. Da diáspora: identidades e mediações culturais. Belo Horizonte: Editora UFMG; Brasília: Representação da Unesco no Brasil, 2003.

HALL, Stuart. A identidade cultural na pós-modernidade. Trad. Tomaz Tadeu da Silva e Guaracira Lopes Louro. 11 ed. - Rio de Janeiro: DP\&A, 2006.

HALL, Stuart. Identidade cultural e diáspora. Revista do Patrimônio Histórico e Artístico Nacional, Brasília, n. 24, 2006, p. 68-75.

HALL, Stuart. \& JEFFERSON, Thomas. Resistance through rituals; youth subcultures in post-war Britain. London - Huchtinson and Co, CCS, University of Birmingham, 1976. 
HERSCHMANN, Micael. (org). Abalando os anos 90: funk e hip hop. Rio de Janeiro: Rocco, 1997.

HERSCHMANN, Micael. O Funk e o hip hop invadem a cena. Rio de Janeiro - Editora UFRJ, 2000.

HOBSBAWM, Eric J. História social do jazz. Trad. Ângela Noronha. Rio de Janeiro: Paz e Terra, 1989.

HOBSBAWM, Eric. J. A era dos extremos: o breve século XX: 1914-1991. São Paulo: Companhia das Letras, 1995.

HOOK, Sue Vander. Hip hop fashion. Mankato: Capstone Press, 2010.

LEAL, Sérgio José de Machado. Acorda hip-hop!: despertando um movimento em transformação. Rio de Janeiro: Aeroplano, 2007.

LIPOVETSKY, Gilles. 0 império do efêmero: a moda e seu destino nas sociedades modernas. São Paulo: Companhia das Letras, 1989.

MUNANGA, Kabengele. Negritude: usos e sentidos. Belo Horizonte: Autêntica, 2009.

PINHO, Patrícia de Santana. Reinvenções da África na Bahia. São Paulo: Annablume, 2004.

POLHEMUS, Ted. Streetstyle: from the sidewalk o the catwalk. London: Thamesand Hudson, 1994.

ROMERO, Elena. FreeStylin' how hip hop changed the fashion industry. Connecticut: Praeger, 2012.

SILVA, José Carlos Gomes da. Os Sub-urbanos e a outra face da cidade - Negros em São Paulo (1900- 1930): cotidiano, lazer e cidadania. 1990. 195 f. Dissertação (Mestrado em Antropologia Social) - Universidade Estadual de Campinas (Unicamp), Campinas, 1990.

SILVA, José Carlos Gomes da. Rap na cidade de São Paulo: música, etnicidade e experiência urbana. 1988. 285 f. Tese (Doutorado em Ciências Sociais) - Universidade Estadual de Campinas (Unicamp). Campinas, 1998.

SILVA, Tomaz Tadeu (org. e trad.) Identidade e diferença: a perspectiva dos estudos culturais. Petrópolis: Vozes, 2000.

STEVEnSON, N.J. Cronologia da Moda: de Maria Antonieta a Alexander Mcqueen. Trad. Maria Luiza X. de A. Borges. Rio de Janeiro: Zahar, 2012. 
STOUTE, Steve; RIVAS, Mim Eichler. The tanning of America: how hip hop created a culture thatre wrote the rules of the new economy. New York: Penguin Group, 2011.

VIANNA, Hermano. 0 baile funk carioca: festas e estilos de vida metropolitanos. 1987. 108 f. Dissertação (Mestrado em Antropologia Social) - Universidade Federal do Rio de Janeiro, (UFRJ), Rio de Janeiro, 1987.

XAVIER, Giovanna. Segredos de penteadeira: conversas transnacionais sobre raça, beleza e cidadania na imprensa negra pós abolição do Brasil e dos EUA. Estud. Hist. (RioJ.) Rio de Janeiro v. 26 n. 52 - july/dec. 2013. Disponível em: www.scielo.br/scielo.php?pid=S010321862013000200009\&script=sci_arttext. Acesso em: 15 jan. 2015 